\title{
Chromosome Instability and Oxidative Stress Markers in Patients with Ataxia Telangiectasia and Their Parents
}

\author{
Luciane Bitelo Ludwig, ${ }^{1,2}$ Victor Hugo Valiati, ${ }^{2}$ Roberta Passos Palazzo, ${ }^{1}$ \\ Laura Bannach Jardim, ${ }^{1}$ Darlan Pase da Rosa, ${ }^{3}$ Silvia Bona, ${ }^{3}$ Graziela Rodrigues, ${ }^{3}$ \\ Norma Possa Marroni, ${ }^{3,4}$ Daniel Prá, ${ }^{5}$ and Sharbel Weidner Maluf ${ }^{1}$ \\ ${ }^{1}$ Medical Genetics Service, Hospital de Clínicas de Porto Alegre, Rua Ramiro Barcelos 2350, 90035-903 Porto Alegre, RS, Brazil \\ ${ }^{2}$ Toxicology and Molecular Biology Laboratory, Universidade do Vale do Rio dos Sinos-UNISINOS, Avenida Unisinos, \\ 950, 93.022-000 São Leopoldo, RS, Brazil \\ ${ }^{3}$ Experimental Hepatology Laboratory, Hospital de Clínicas de Porto Alegre-HCPA, Rua Ramiro Barcelos, \\ 2350, 90035-903 Porto Alegre, RS, Brazil \\ ${ }^{4}$ Oxidative Stress Laboratory, Universidade Luterana do Brasil-ULBRA, Avenida Farroupilha 8001, 92425-900 Canoas, RS, Brazil \\ ${ }^{5}$ Graduate Course in Health Promotion, Universidade de Santa Cruz do Sul (UNISC), Avenida Independência 2293, \\ 96815-900 Santa Cruz do Sul, RS, Brazil
}

Correspondence should be addressed to Sharbel Weidner Maluf; 0808swm@gmail.com

Received 6 April 2013; Revised 9 June 2013; Accepted 17 June 2013

Academic Editor: Vanina Heuser

Copyright (c) 2013 Luciane Bitelo Ludwig et al. This is an open access article distributed under the Creative Commons Attribution License, which permits unrestricted use, distribution, and reproduction in any medium, provided the original work is properly cited.

\begin{abstract}
Ataxia telangiectasia (AT) is a rare neurodegenerative disorder, inherited in an autosomal recessive manner. Total blood samples were collected from 20 patients with AT, 13 parents of patients, and 17 healthy volunteers. This study aimed at evaluating the frequency of chromosomal breaks in spontaneous cultures, induced by bleomycin and ionizing radiation, and further evaluated the rates of oxidative stress in AT patients and in their parents, compared to a control group. Three cell cultures were performed to each individual: the first culture did not receive induction to chromosomal instability, the second was exposed to bleomycin, and the last culture was exposed to ionizing radiation. To evaluate the rates of oxidative stress, the markers superoxide dismutase (SOD), catalase (CAT), and thiobarbituric acid (TBARS) were utilized. Significant differences were observed between the three kinds of culture treatments (spontaneous, bleomycin, and radiation induced) and the breaks and chromosomal aberrations in the different groups. The oxidative stress showed no significant differences between the markers. This study showed that techniques of chromosomal instability after the induction of ionizing radiation and bleomycin are efficient in the identification of syndrome patients, with the ionizing radiation being the most effective.
\end{abstract}

\section{Introduction}

Ataxia telangiectasia (AT) is a rare neurodegenerative disorder, autosomal recessive inherited $[1,2]$. The carriers are apparently born normal; however, by 2-3 years old, clinical manifestations appear. The frequency of occurrence of the syndrome in the United States is approximately one in 40,000 live births [3].

Ataxic movements and ocular telangiectasia are among the pathological manifestations [4-7]. AT syndrome is caused by a mutation in the gene located on chromosome 11q22-23 encoding the protein ATM kinase [2,8]. ATM recognizes double-stranded breaks in DNA and signals the cell-cycle checkpoints [2].

AT patients are sensitive to ionizing radiation $[9,10]$ and have chromosomal instability, defects in cell-cycle checkpoints $[2,11]$, and, therefore, increased risk of developing cardiovascular disease and cancer $[6,12]$. Hypersensitivity and chromosomal instability characteristic of AT patients can be evaluated through the high frequency of chromosomal breaks and gaps, rearrangements, aneuploidy, and translocations [13-15] observed in cells spontaneous carriers [16] or 
in cells exposed to mutagens [13-15]. Furthermore, patients with AT exhibit high rates of chromosomal rearrangements involving autosomal chromosomes 7 and 14. Changes are often found as translocations and inversions involving these chromosomes [17].

Chronic oxidative stress is a common feature of AT $[14,18]$, but the involvement of ATM protein or the degree of oxidative stress is not elucidated. Bleomycin is already widely used in the evaluation of chromosomal instability in patients with clinical suspicion of AT, but is rarely used as a supplementary examination or routine for the parents of these patients. Based on this, the present work is to provide important information to incorporate new routine tests in identifying patients with AT. Early identification of these is of paramount importance for prenatal counseling, diagnosis, improvement or insertion and treatments for the various manifestations of the disease. The early diagnosis of AT would help in the prevention of cancer, where there is an increased frequency of this disease among patients and their parents.

In this sense, the present study evaluated the frequency of spontaneous, radiation-induced and bleomycin-induced chromosome breakage, as well as the level of oxidative stress in AT patients and parents of patients with the syndrome by comparing the results with the control group.

\section{Materials and Methods}

2.1. Patients and Blood Sampling. This study was developed at the Cytogenetics Laboratory from the Medical Genetics Service of the Hospital de Clínicas de Porto Alegre, Brazil, between August 2011 and June 2012. We evaluated the chromosomal instability and oxidative stress in blood cells sampled from 20 AT patients, aged $15.3 \pm 10.2$ years and 13 parents aged $41.0 \pm 10.6$ years of the AT patients. The control group was composed of 17 healthy individuals aged $22.4 \pm 13.4$ years.

Subjects were enrolled after signing an informed consent term in accordance with the guidelines of the Ethics Committee at Hospital de Clínicas de Porto Alegre (HCPA), RS, Brazil. Ten-milliliter samples of heparinized peripheral blood were collected, immediately protected from light, and stored at $4^{\circ} \mathrm{C}$ for evaluation. All subjects answered the personal health questionnaire of the Commission for Protection Against Environmental Mutagens and Carcinogens (ICPEMC).

2.2. Cell Cultures, Treatments, and Chromosome Preparations. For the chromosomal instability analysis, three cell cultures were performed to each individual included in this study. A protocol adapted from 1960 [19] was used. Slides were stained with GTG-banding technique [20].

The first culture did not receive induction to chromosomal instability, thereby representing the spontaneous cultures of each individual. The second culture was exposed to bleomycin $(6 \mu \mathrm{g} / \mathrm{mL}$ of culture). The third culture was exposed to $3 \mathrm{~Gy}$ (ionizing radiation from a ${ }^{137} \mathrm{Cs} \gamma$-ray source). The irradiation was performed at the Gamma Cell 1000 Elite irradiator.

The breaks and chromosomal aberrations observed in the three treatments of all individuals groups were reported.
A minimum of 4 and a maximum of 50 metaphases made by culture were analysed, depending on the cell growth of each culture. Chromosomal aberrations were classified as chromatid breaks (chtb), chromosome breaks (chrb), chromosome fragments, translocations ( $\mathrm{t}$ ), deletions (del), interstitial deletions, dicentric chromosomes, triradial and quadriradial figures, Rings chromosome (r), Additional materials (add), isochromosomes (iso), chromatid failures (chtg), chromosomal failures (chrg), and fragile sites.

To calculate the frequency of chromosomal instability flaws and fragile sites were excluded, because they are not considered chromosome breakage. The other changes were included in the count, and the number of breaks for each occurrence of each chromosome abnormality observed was recorded.

2.3. Definition of Chromosomal Changes. The chromosome breaks are defined as all discontinuities in the chromosome that are experiencing a greater distance than the width of a chromatid, which may involve one (chtb) or both chromatids (chrb) breaks giving rise to acentric chromosome fragments [21]. The translocations are formed when there is an exchange of portions of two or more chromosomes [22]. Deletions are characterized by the loss of a portion of a chromosome. These deletions can be terminal (del) or interstitial (interstitial deletion). Interstitial deletions are defined when there is loss of a middle segment of the chromosome [22]. The chromosomes are dicentric chromosomes with two centromeres. They are formed from two chromosomes break and union portions of centromere [22]. The figures are chromosomal rearrangements involving more than one chromosome and more than one break point, which can be classified as either triradial or quadriradial [23]. The chromosomal rings are formed when there is loss of telomeric portions of chromosomes resulting from the union of edges forming a circular chromosome [22]. Additional materials of unknown origin were classified as add. These additional materials can be formed by insertion, duplication, or translocation of chromosome segments [22]. Isochromosome is formed when a loss occurs in a portion of the chromosome and the other portion is doubled [22]. Failures chromatid and chromosomal are defined as all discontinuities in one (chtg) or both chromatids (chrg) of chromosomes that have a distance less than one chromatid [21]. The fragile sites are regions where there is abnormal chromatin compaction [24]. They are viewed as a glitch in the chromosome.

2.4. Oxidative Stress. For preparation of the samples, $5 \mathrm{~mL}$ of whole blood was collected from each patient. The samples were centrifuged for 5 minutes at a speed of 3000 RPM. After centrifugation, plasma was separated from red blood cells using a disposable Pasteur pipette. The plasma was stored in an Eppendorf.

Red blood cells were centrifuged for 5 minutes at a speed of 3000 RPM and washed three times with saline solution. After washing, the red blood was collected and stored in a $1.5 \mathrm{~mL}$ Eppendorf with a buffer prepared with magnesium sulfate $\left(\mathrm{MgSO}_{4}\right)$ and acetic acid. The Eppendorf's plasma 
TABLE 1: Frequency of chromosomal breaks observed in the different groups and treatments.

\begin{tabular}{|c|c|c|c|}
\hline \multicolumn{4}{|c|}{ Frequency of chromosomal breaks } \\
\hline & Spontaneous & Bleomycin $(6 \mu \mathrm{g} / \mathrm{mL})$ & Radiation (3 Gy) \\
\hline \multicolumn{4}{|l|}{ Patients } \\
\hline Frequency $(\min \times \max )$ & $0.00-1.30$ & $0.43-5.65$ & $0.47-7.32$ \\
\hline$\chi$ frequencies/cell & 0.18 & 1.63 & 2.10 \\
\hline$N^{\circ}$ cells $(\min \times \max )$ & $30 \times 50$ & $30 \times 50$ & $30 \times 50$ \\
\hline \multicolumn{4}{|l|}{ Parents } \\
\hline Frequency $(\min \times \max )$ & $0.00-0.13$ & $0.00-1.27$ & $0.23-0.93$ \\
\hline$\chi$ frequencies/cell & 0.02 & 0.56 & 0.52 \\
\hline$N^{\circ}$ cells $(\min \times \max )$ & $30 \times 50$ & $5 \times 50$ & $21 \times 50$ \\
\hline \multicolumn{4}{|l|}{ Control group } \\
\hline Frequency $(\min \times \max )$ & $0.00-0.03$ & $0.00-0.90$ & $0.10-0.93$ \\
\hline$\chi$ frequencies/cell & 0.01 & 0.47 & 0.56 \\
\hline$N^{\circ}$ cells $(\min \times \max )$ & 30 & $4 \times 30$ & $13 \times 30$ \\
\hline
\end{tabular}

$\chi$ : average frequency of chromosomal breaks per cell.

and red blood cells were stored in a freezer at $-80^{\circ} \mathrm{C}$ until processing.

To assess oxidative stress, markers TBARS (thiobarbituric acid), SOD (superoxide dismutase), and CAT (catalase) were used.

2.5. Measure of Substances That React in TBARS. The technique of TBARS is the sample heating with thiobarbituric acid and the consequent formation of a colored product, measured in a spectrophotometer at $535 \mathrm{~nm}$. The occurrence of staining is due to the presence of Malondialdehyde (MDA: an indicator of oxidative stress) and other substances from lipid peroxidation in biological material. Plasma samples were placed in test tubes with $0.75 \mathrm{~mL}$ of trichloroacetic acid (TCA) $10 \%, 0.25 \mathrm{~mL}$ of homogenate, $0.5 \mathrm{~mL}$ of thiobarbituric acid (TBARS) $0.67 \%$, and $25 \mathrm{~mL}$ of distilled water. The tubes were stirred and heated to a temperature of $100^{\circ} \mathrm{C}$. After the tubes were cooled, $1.5 \mathrm{~mL}$ of n-butyl alcohol was added, to extract the pigment formed. After that the samples were placed in a shaker (Biomatic) for 45 seconds and centrifuged for 10 minutes at 3000 RPM $(1110 \times \mathrm{g})$. Finally, the colored product was removed and read in spectrophotometer (CARY 3E-UV-Visible Spectrophotometer Varian) with a wavelength of $535 \mathrm{~nm}$. The concentration of TBARS obtained was expressed in ng per mg total protein $[25,26]$.

2.6. Evaluation of the Activity of CAT. The rate of decomposition of hydrogen peroxide $\left(\mathrm{H}_{2} \mathrm{O}_{2}\right)$ is measured spectrophotometrically at $240 \mathrm{~nm}$, and this wavelength $\mathrm{H}_{2} \mathrm{O}_{2}$ has maximum absorbance. An incubation mixture containing a final volume of $1000 \mu \mathrm{L}$ with reagents was prepared: $50 \mathrm{mM}$ phosphate buffer, $\mathrm{pH} 7.4$ and $0.3 \mathrm{M} \mathrm{H}_{2} \mathrm{O}_{2}$. In quartz cuvette, $955 \mu \mathrm{L}$ phosphate buffer and $25 \mu \mathrm{L}$ plasma were added, which were placed in the apparatus and minus the blank. $20 \mu \mathrm{L}$ of hydrogen peroxide was added and readings were performed at $240 \mathrm{~nm}$. The results were expressed as pmoles/g tissue per mg total protein $[26,27]$.
TABLE 2: Statistical analysis comparing the frequency of breaks of different treatments for each group.

\begin{tabular}{lcccc}
\hline Groups & Treatments & $\begin{array}{c}P \text { value of the } \\
\text { Bleomycin } \\
(6 \mu \mathrm{g} / \mathrm{mL})\end{array}$ & $\begin{array}{c}\text { Radiation } \\
(3 \mathrm{~Gy})\end{array}$ & $\begin{array}{l}\text { Friedman test } \\
\text { Patients }\end{array}$ \\
$\begin{array}{l}\text { Parents } \\
\text { Control } \\
\text { group }\end{array}$ & $\mathrm{a}$ & $\mathrm{a}, \mathrm{b}$ & $\mathrm{b}$ & 0.006 \\
\hline
\end{tabular}

Treatments with at least one letter in common exhibit similar frequency of breaks $(\alpha=0.05)$.

2.7. Evaluation of the Activity of SOD. The technique for determination of SOD, second Misra and Fridovich [28], is based on inhibition of the formation of superoxide dismutase in adrenochrome autoxidation of epinephrine. Whereas epinephrine remains stable in acidic solutions and spontaneously oxidizes in basic solutions, favoring the formation of adrenochrome, SOD can be measured spectrophotometrically by following the change in absorbance at $480 \mathrm{~nm}$ of epinephrine which has a peak absorbance. To perform the reaction, a mixture was prepared with a final volume of $1 \mathrm{~mL}$ with bicarbonate buffer $(0.05 \mathrm{M}, \mathrm{pH} 10.2)$ and plasma epinephrine $(4 \mathrm{mM})$. The absorbance used was $480 \mathrm{~nm}$, at $30^{\circ} \mathrm{C}$. The line pattern was developed with increasing concentrations of SOD (20-100 nM) to determine the concentration that produces the same whether the inhibition of autoxidation of epinephrine by $50 \%$, and the results were expressed as USOD/mg of total protein. An enzyme activity is defined as the amount of enzyme which is able to inhibit $50 \%$ of autoxidation of epinephrine [26].

2.8. Quantification of Total Protein. For the quantification of total protein, the method of Bradford [29] was used. The Bradford method is a technique for determining total protein using the Coomassie Brilliant Blue dye BG-250. This 
TABLE 3: Statistical analysis comparing the chromosomal aberrations (CAs) between the different groups within each treatment.

\begin{tabular}{|c|c|c|}
\hline Treatments & Chromosomal aberrations & $P$ value of the Kruskal-Wallis test \\
\hline Spontaneous & \multirow{3}{*}{ Chromatid breaks (chtb) } & 0.910 \\
\hline Bleomycin $(6 \mu \mathrm{g} / \mathrm{mL})$ & & $0.007^{*}$ \\
\hline Radiation (3 Gy) & & $0.000^{*}$ \\
\hline Spontaneous & \multirow{3}{*}{ Chromosome breaks (chrb) } & 0.289 \\
\hline Bleomycin $(6 \mu \mathrm{g} / \mathrm{mL})$ & & $0.036^{*}$ \\
\hline Radiation (3 Gy) & & 0.197 \\
\hline Spontaneous & \multirow{3}{*}{ Chromosome fragments } & $0.022^{*}$ \\
\hline Bleomycin $(6 \mu \mathrm{g} / \mathrm{mL})$ & & $0.009^{*}$ \\
\hline Radiation (3 Gy) & & 0.270 \\
\hline Spontaneous & \multirow{3}{*}{ Translocations (t) } & 0.097 \\
\hline Bleomycin $(6 \mu \mathrm{g} / \mathrm{mL})$ & & 0.100 \\
\hline Radiation (3 Gy) & & $0.004^{*}$ \\
\hline Spontaneous & \multirow{3}{*}{ Deletions (del) } & $0.002^{*}$ \\
\hline Bleomycin $(6 \mu \mathrm{g} / \mathrm{mL})$ & & 0.073 \\
\hline Radiation (3 Gy) & & $0.004^{*}$ \\
\hline Spontaneous & \multirow{3}{*}{ Interstitial deletions } & 1.000 \\
\hline Bleomycin $(6 \mu \mathrm{g} / \mathrm{mL})$ & & 0.293 \\
\hline Radiation (3 Gy) & & 1.000 \\
\hline Spontaneous & \multirow{3}{*}{ Dicentric chromosomes } & 1.000 \\
\hline Bleomycin $(6 \mu \mathrm{g} / \mathrm{mL})$ & & 0.439 \\
\hline Radiation (3 Gy) & & 1.000 \\
\hline Spontaneous & \multirow{3}{*}{ Triradial figures } & 1.000 \\
\hline Bleomycin $(6 \mu \mathrm{g} / \mathrm{mL})$ & & $0.005^{*}$ \\
\hline Radiation (3 Gy) & & $0.001^{*}$ \\
\hline Spontaneous & \multirow{3}{*}{ Quadriradial figures } & 1.000 \\
\hline Bleomycin $(6 \mu \mathrm{g} / \mathrm{mL})$ & & 0.228 \\
\hline Radiation (3 Gy) & & 0.222 \\
\hline Spontaneous & \multirow{3}{*}{ Ring chromosomes (r) } & 1.000 \\
\hline Bleomycin $(6 \mu \mathrm{g} / \mathrm{mL})$ & & 0.587 \\
\hline Radiation (3 Gy) & & 0.943 \\
\hline Spontaneous & \multirow{3}{*}{ Additional materials (add) } & 1.000 \\
\hline Bleomycin $(6 \mu \mathrm{g} / \mathrm{mL})$ & & 1.000 \\
\hline Radiation (3 Gy) & & 0.287 \\
\hline Spontaneous & \multirow{3}{*}{ Isochromosomes (iso) } & 1.00 \\
\hline Bleomycin $(6 \mu \mathrm{g} / \mathrm{mL})$ & & 0.293 \\
\hline Radiation (3 Gy) & & 1.00 \\
\hline Spontaneous & \multirow{3}{*}{ Chromatid failures (chtg) } & $0.027^{*}$ \\
\hline Bleomycin $(6 \mu \mathrm{g} / \mathrm{mL})$ & & 0.461 \\
\hline Radiation (3 Gy) & & $0.014^{*}$ \\
\hline Spontaneous & \multirow{3}{*}{ Chromosomal failures (chrg) } & 0.557 \\
\hline Bleomycin $(6 \mu \mathrm{g} / \mathrm{mL})$ & & $0.021^{*}$ \\
\hline Radiation (3 Gy) & & 0.461 \\
\hline Spontaneous & \multirow{3}{*}{ Fragile sites } & 0.591 \\
\hline Bleomycin $(6 \mu \mathrm{g} / \mathrm{mL})$ & & 0.314 \\
\hline Radiation (3 Gy) & & $0.004^{*}$ \\
\hline
\end{tabular}

*demonstrates the chromosomal aberrations with statistically significant differences. 
method is based on the interaction between the dye BG-250 proteins and macromolecules containing amino acids basic side chains or aromatic amino acids. In the reaction $\mathrm{pH}$, the interaction between the protein and the high molecular weight dye BG-250 causes the displacement of the equilibrium to form anionic dye, which absorbs strongly at $595 \mathrm{~nm}$ in a spectrophotometer [30].

2.9. Statistical Analysis. To evaluate the difference of the frequencies of chromosomal breaks between the different treatments (Spontaneous, bleomycin, and radiation) in each group (patients, parents, or controls) the Friedman test was used.

Statistical analysis of chromosomal abnormalities and total number of breaks between different groups and treatments were performed using the Kruskal-Wallis test. The correlation between total chromosome breakage and different oxidative stress markers was performed using the Spearman test. When statistical analysis showed significant results, post hoc Bonferroni correction was concucted. Multiple comparisons were performed with SPSS, version 15.0, with a significance level of 0.05 .

\section{Results and Discussion}

The sample number and analyzed cells varied depending on the difficulty of each individual cell growth. The rates of cell growth were variable among individuals sampled and from culture to culture. Overall, we observed a sharp decline in growth in the cultures of the group of patients among the three treatments, as described next. Cell growth failure was observed: in patients: $45 \%$ samples included in spontaneous and radiation treatments, and $50 \%$ samples on treatment with Bleomycin; in parents: $7.7 \%$ samples in spontaneous and radiation treatments, and $23.08 \%$ in the sample on treatment with Bleomycin and in controls: $23.53 \%$ samples in treating spontaneous and $11.76 \%$ in the treatment with radiation and Bleomycin.

Regarding the frequency of chromosome breakage, the average of those in the spontaneous treatment of patients with AT demonstrated to be increased compared to the control group, as shown in Table 1. In relation to treatment with induction of DNA damage, patients with AT demonstrated hypersensitivity to the effects of bleomycin and ionizing radiation compared to the control group, confirming what has been described by Huo et al. [9], Sun et al. [10], Abraham [31], and Barzilai et al. [32] (Table 1). Hypersensitivity for bleomycin was demonstrated to be about three times higher than that recorded in the parent groups and controls. Already, hypersensitivity to ionizing radiation proved to be about four times higher in the group of patients than that observed in the groups of parents and controls.

The average frequency of chromosome breakage in parents was almost similar to that obtained by the control group, showing no significant differences as observed in the study by Sun et al. [10] (Table 1).

Statistically, the frequency of chromosomal breaks observed in the three treatments showed significant differences $(\alpha=0.05)$ in patients, parents, and controls, as shown
TABLE 4: Statistical analysis comparing the total number of breaks in each treatment between the different groups.

\begin{tabular}{lcccc}
\hline Treatments & Patients & Parents & $\begin{array}{c}\text { Control } \\
\text { group }\end{array}$ & $\begin{array}{c}\text { Krulue of the } \\
\text { Kruskal-Wallis test }\end{array}$ \\
\hline $\begin{array}{l}\text { Spontaneous } \\
\begin{array}{l}\text { Bleomycin } \\
(6 \mu \mathrm{g} / \mathrm{mL})\end{array}\end{array}$ & $\mathrm{a}$ & $\mathrm{a}, \mathrm{b}$ & $\mathrm{b}$ & 0.007 \\
$\begin{array}{l}\text { Radiation } \\
(3 \mathrm{~Gy})\end{array}$ & $\mathrm{a}$ & $\mathrm{b}$ & $\mathrm{b}$ & 0.001 \\
\hline
\end{tabular}

Treatments with at least one letter in common exhibit similar number of breaks $(\alpha=0.05)$.

in Table 2, and in the breaks and chromosomal aberrations in the different groups (Table 3). Increased rearrangements were not observed involving the chromosomes 7 and 14 .

Statistically, the total number of breaks in each of the different treatment groups showed significant differences (Table 4). In spontaneous treatment, differences were observed between patients and controls, and for treatment with bleomycin and radiation, such differences were observed between patients and parents and between patients and controls (Table 4).

No significant differences were observed between different markers of oxidative stress, as shown in Table 5.

The correlation analysis between the total number of breaks of the spontaneous treatment in each group relative to each index marker of oxidative stress showed no significant differences, as shown in Table 6.

A factor that may have influenced the growth of these cultures was the amount of DNA damage generated after induction with bleomycin and radiation. The damage caused to the DNA interferes with their replication, triggering mutations, various types of chromosomal abnormalities, or cell death by apoptosis [33]. For microscopic analysis, cells are stationed in metaphase by the use of colchicine-in this stage, the cells have been through the process of repairing damage $\left(G_{2}\right.$ phase), where cells that have undergone higher levels of DNA damage are eliminated via apoptosis. Gilad et al. [34] showed that ionizing radiation inhibited cell growth in the 6 patients who were included in the study, proving the difficulty of cell growth in patients with the syndrome.

The variation in the amount of cells analyzed for each patient may have influenced the low rates of chromosomal rearrangements involving chromosomes 7 and 14 in patients with AT observed. It was then possible to observe that the evaluation techniques of chromosomal instability after exposure to ionizing radiation or bleomycin are effective in identifying patients with the syndrome, and ionizing radiation was considered the most effective.

Prospects are expected to increase the sample size to conduct further sampling of patients and standardizing the number of cells analyzed. A much more detailed analysis of each patient was developed in order to make more accurate assessments by chromosomal abnormalities and indices of oxidative stress. The inclusion of the analysis of the marker of oxidative stress glutathione peroxidase (GPx) is also 
TABLE 5: Average indices of oxidative stress observed.

\begin{tabular}{lccc}
\hline & $\begin{array}{c}\text { TBARS } \\
\text { (ng/mg prot.) }\end{array}$ & $\begin{array}{c}\text { CAT } \\
\text { (pg/mg prot.) }\end{array}$ & $\begin{array}{c}\text { SOD } \\
\text { (USOD/mg prot.) }\end{array}$ \\
\hline$\chi$ Patients & 3.36 & 1.11 & 21.16 \\
$\chi$ Parents & 3.03 & 0.95 & 27.04 \\
$\begin{array}{l}\chi \text { Control } \\
\text { group }\end{array}$ & 3.42 & 0.73 & 20.79 \\
\hline
\end{tabular}

$\chi$ : average indices of oxidative stress observed.

TABLE 6: Correlation of the total number of spontaneous breaks of treatment of each group in relation to indexes of different markers of oxidative stress.

\begin{tabular}{|c|c|c|c|c|}
\hline \multirow{2}{*}{ Groups } & \multicolumn{3}{|c|}{ Markers of oxidative stress } & \\
\hline & TBARS & CAT & SOD & \\
\hline Patients & 0.774 & 0.518 & 0.200 & \multirow{3}{*}{$\begin{array}{l}P \text { value of the } \\
\text { Spearman } \\
\text { correlation }\end{array}$} \\
\hline Parents & 1.000 & 0.809 & 0.499 & \\
\hline Control group & 0.222 & 0.223 & 0.631 & \\
\hline
\end{tabular}

$(\alpha=0.05)$.

expected. The GPx develops its role in situations where there are low levels of hydrogen peroxide, while CAT operates in situations of high concentrations $[35,36]$. Therefore, with the inclusion of this marker and with the addition of a larger number of patients, it will be possible to measure reliably whether or not this happening oxidative stress is strong evidence in patients with AT.

\section{Acknowledgments}

The authors thank all the volunteers who participated in the study and the financial support provided by the Research and Event Incentive Fund from Hospital de Clínicas de Porto Alegre (FIPE/HCPA) and Brazilian National Research Council (CNPq).

\section{References}

[1] E. Boder, "Ataxia-telangiectasia: an overview," Kroc Foundation Series, vol. 19, pp. 1-63, 1985.

[2] M. F. Lavin, "Ataxia-telangiectasia: from a rare disorder to a paradigm for cell signalling and cancer," Nature Reviews Molecular Cell Biology, vol. 9, no. 10, pp. 759-769, 2008.

[3] H. H. Chun and R. A. Gatti, "Ataxia-telangiectasia, an evolving phenotype," DNA Repair, vol. 3, no. 8-9, pp. 1187-1196, 2004.

[4] T. O. Crawford, "Ataxia telangiectasia," Seminars in Pediatric Neurology, vol. 5, no. 4, pp. 287-294, 1998.

[5] R. A. Gatti, S. Becker-Catania, H. H. Chun et al., "The pathogenesis of ataxia-telangiectasia: learning from a Rosetta Stone," Clinical Reviews in Allergy and Immunology, vol. 20, no. 1, pp. 87-108, 2001.

[6] P. J. McKinnon, "ATM and ataxia telangiectasia: second in molecular medicine review series," EMBO Reports, vol. 5, no. 8, pp. 772-776, 2004.

[7] R. P. Sedgwick and E. Boder, "Ataxia-telangiectasia," in Handbook of Clinical Neu-Rology, vol. 16, pp. 347-423, Elsevier Scientific, 1991.
[8] K. Savitsky, A. Bau-Shira, S. Gilad et al., "A single ataxia telangiectasia gene with a product similar to Pl-3 kinase," Science, vol. 268, no. 5218, pp. 1749-1753, 1995.

[9] Y. K. Huo, Z. Wang, J.-H. Hong et al., "Radiosensitivity of ataxia-telangiectasia, X-linked agammaglobulinemia, and related syndromes using a modified colony survival assay," Cancer Research, vol. 54, no. 10, pp. 2544-2547, 1994.

[10] X. Sun, S. G. Becker-Catania, H. H. Chun et al., "Early diagnosis of ataxia-telangiectasia using radiosensitivity testing," Journal of Pediatrics, vol. 140, no. 6, pp. 724-731, 2002.

[11] M. F. Lavin and Y. Shiloh, "The genetic defect in ataxiatelangiectasia," Annual Review of Immunology, vol. 15, pp. 177202, 1997.

[12] F. Gumy-Pause, P. Wacker, and A.-P. Sappino, "ATM gene and lymphoid malignancies," Leukemia, vol. 18, no. 2, pp. 238-242, 2004.

[13] M. F. Lavin, G. Birrell, P. Chen, S. Kozlov, S. Scott, and N. Gueven, "ATM signaling and genomic stability in response to DNA damage," Mutation Research, vol. 569, no. 1-2, pp. 123-132, 2005.

[14] R. Reliene and R. H. Schiestl, "Antioxidants suppress lymphoma and increase longevity in Atm-deficient mice," Journal of Nutrition, vol. 137, no. 1, pp. S229-S232, 2007.

[15] Y. Shiloh, "ATM and related protein kinases: safeguarding genome integrity," Nature Reviews Cancer, vol. 3, no. 3, pp. 155$168,2003$.

[16] P. Pérez-Vera, A. González-del Angel, B. Molina et al., "Chromosome instability with Bleomycin and X-ray hypersensitivity in a boy with Nijmegen Breakage syndrome," The American Journal of Medical Genetics, vol. 70, pp. 24-27, 1997.

[17] P. H. Kohn, J. Whang Peng, and W. R. Levis, "Chromosomal instability in ataxia telangiectasia," Cancer Genetics and Cytogenetics, vol. 6, no. 4, pp. 289-302, 1982.

[18] J. Reichenbach, R. Schubert, D. Schindler, K. Müller, H. Böhles, and S. Zielen, "Elevated oxidative stress in patients with Ataxia telangiectasia," Antioxidants and Redox Signaling, vol. 4, no. 3, pp. 465-469, 2002.

[19] P. S. Moorhead, P. C. Nowell, W. J. Mellman, D. M. Battips, and D. A. Hungerford, "Chromosome preparations of leukocytes cultured from human peripheral blood," Experimental Cell Research, vol. 20, no. 3, pp. 613-616, 1960.

[20] J. A. de Miranda and M. S. Mattevi, "Técnicas de bandeamento e coloração cromossômica," in Citogenética Humana, S. W. Maluf and M. Riegel, Eds., pp. 63-69, Artmed, Porto Alegre, Brazil, 2011.

[21] R. P. Palazzo and S. W. Maluf, "Técnica de aberrações cromossômicas para avaliação do dano de DNA," in Citogenética Humana, S. W. Maluf and M. Riegel, Eds., pp. 169-175, Artmed, Porto Alegre, Brazil, 2011.

[22] R. Mergener, L. B. Ludwig, and S. W. Maluf, "Alterações cromossômicas estruturais," in Citogenética Humana, S. W. Maluf and M. Riegel, Eds., pp. 80-102, Artmed, Porto Alegre, Brazil, 2011.

[23] M. S. Faller, "Diagnóstico genético pré-implantação," in Citogenética Humana, S. W. Maluf and M. Riegel, Eds., pp. 294-316, Artmed, Porto Alegre, Brazil, 2011.

[24] S. Llambi and M. V. Arruga, "Aproximação molecular da região cromossômica frágil Xq31-34 em bovinos (Bos taurus) utilizando microdissecação cromossômica e DOP-PCR," Arquivo Brasileiro de Medicina Veterinária e Zootecnia, vol. 60, no. 4, pp. 926-931, 2008. 
[25] J. A. Buege and S. D. Aust, "Microsomal lipid peroxidation," Methods in Enzymology, vol. 52, pp. 302-310, 1978.

[26] F. Naso, Efeitos da administração da Orgoteína (Superóxido Dismutase Exógena) sobre o Estresse Oxidativo Hepático em Ratos Diabéticos. 2010. 83 f [M.S. thesis], Curso de Pós-Graduação em Ciências Biológicas. Universidade Federal do Rio Grande do Sul, Porto Alegre, Brazil, 2010.

[27] H. Aebi, "Catalase in vitro," Methods in Enzymology, vol. 105, pp. 121-126, 1984.

[28] H. P. Misra and I. Fridovich, "The role of superoxide anion in the autoxidation of epinephrine and a simple assay for superoxide dismutase," Journal of Biological Chemistry, vol. 247, no. 10, pp. 3170-3175, 1972.

[29] M. M. Bradford, "A rapid and sensitive method for the quantitation of microgram quantities of protein utilizing the principle of protein-dye binding," Analytical Biochemistry, vol. 72, pp. 248254, 1976

[30] D. A. M. Zaia, C. T. B. Zaia V, and J. Lichtig, "Determinação de proteínas totais via espectrofotometria: vantagens e desvantagens dos métodos existentes," Química Nova, vol. 21, no. 6, pp. 787-793, 1998.

[31] R. T. Abraham, "Cell cycle checkpoint signaling through the ATM and ATR kinases," Genes and Development, vol. 15, no. 17, pp. 2177-2196, 2001.

[32] A. Barzilai, G. Rotman, and Y. Shiloh, "ATM deficiency and oxidative stress: a new dimension of defective response to DNA damage," DNA Repair, vol. 1, no. 1, pp. 3-25, 2002.

[33] K. K. Khanna, M. F. Lavin, S. P. Jackson, and T. D. Mulhern, "ATM, a central controller of cellular responses to DNA damage," Cell Death and Differentiation, vol. 8, no. 11, pp. 1052-1065, 2001.

[34] S. Gilad, L. Chessa, R. Khosravi et al., "Genotype-phenotype relationships in ataxia-telangiectasia and variants," The American Journal of Human Genetics, vol. 62, no. 3, pp. 551-561, 1998.

[35] A. L. B. Barreiros and J. M. David, "Estresse oxidativo: relação entre geração de espécies reativas e defesa do organismo," Química Nova, vol. 29, pp. 113-123, 2006.

[36] J .M. F. A. Nesto, R. J. B. B. Rivera, R. G. Calvi et al., "Níveis comparativos de estresse oxidativo em camundongos em duas situações do limite orgânico: overreaching induzido por treinamento de natação e câncer," Revista Brasileira De Medicina Do Esporte, vol. 14, no. 6, pp. 548-552, 2008. 

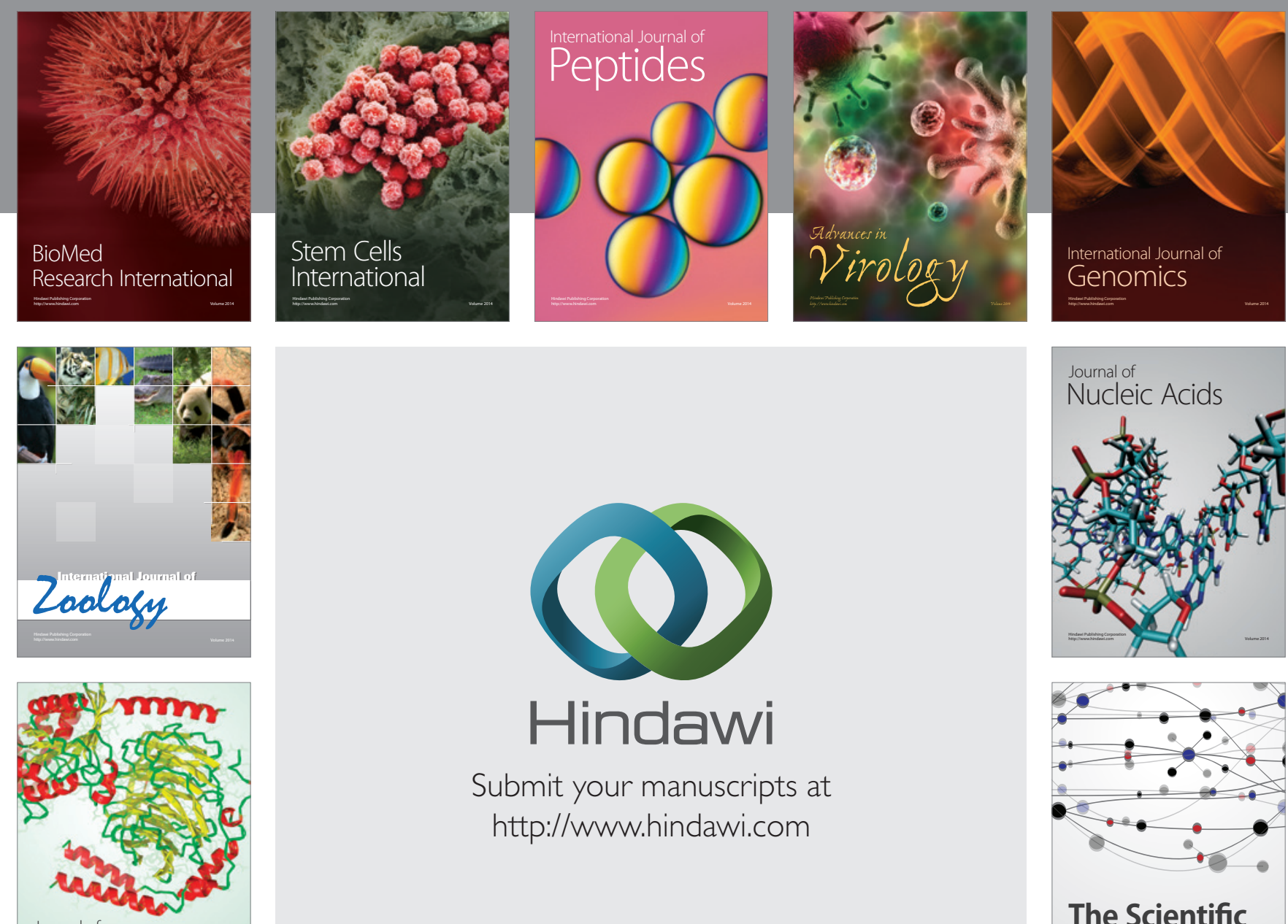

Submit your manuscripts at

http://www.hindawi.com

Journal of
Signal Transduction
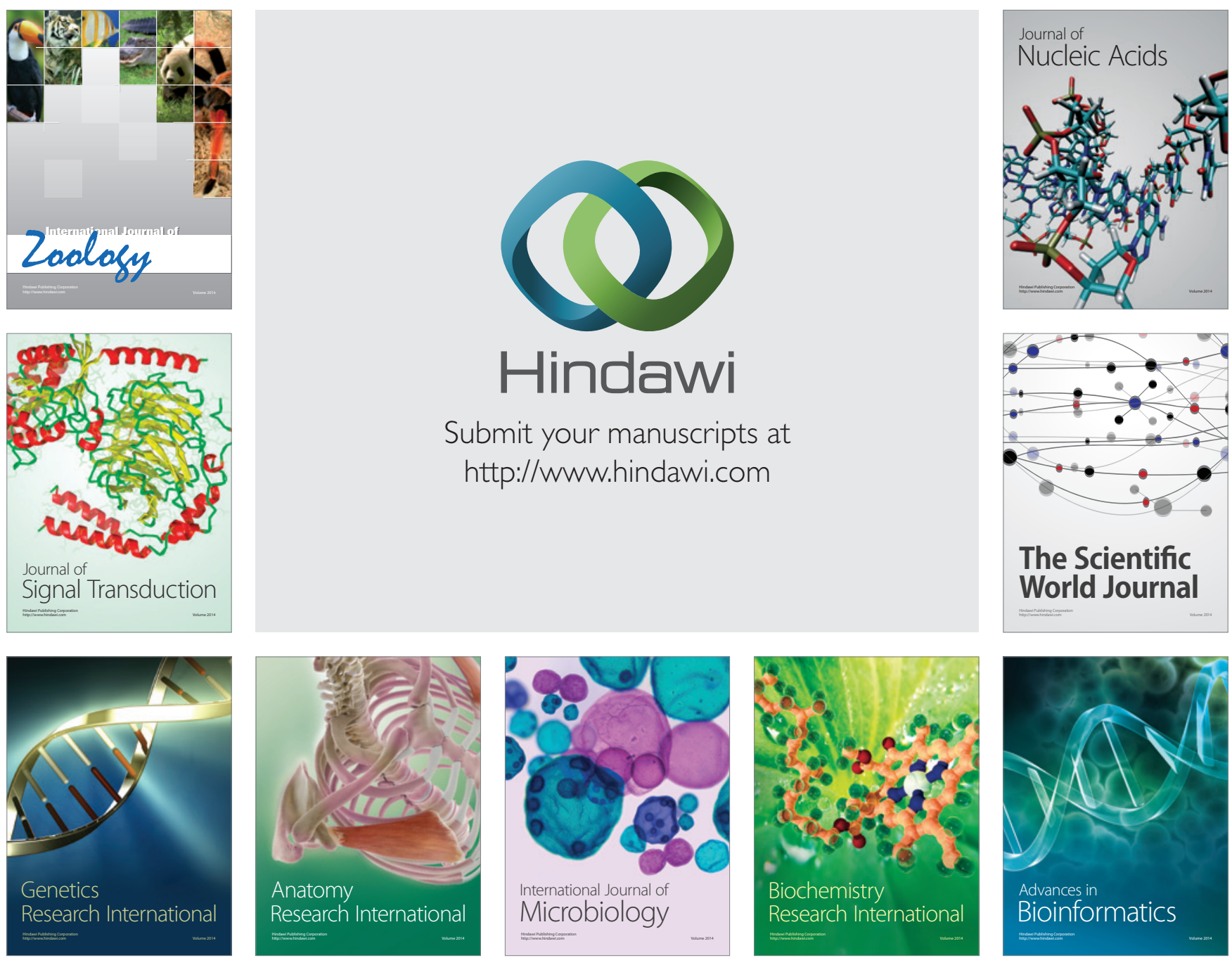

The Scientific World Journal
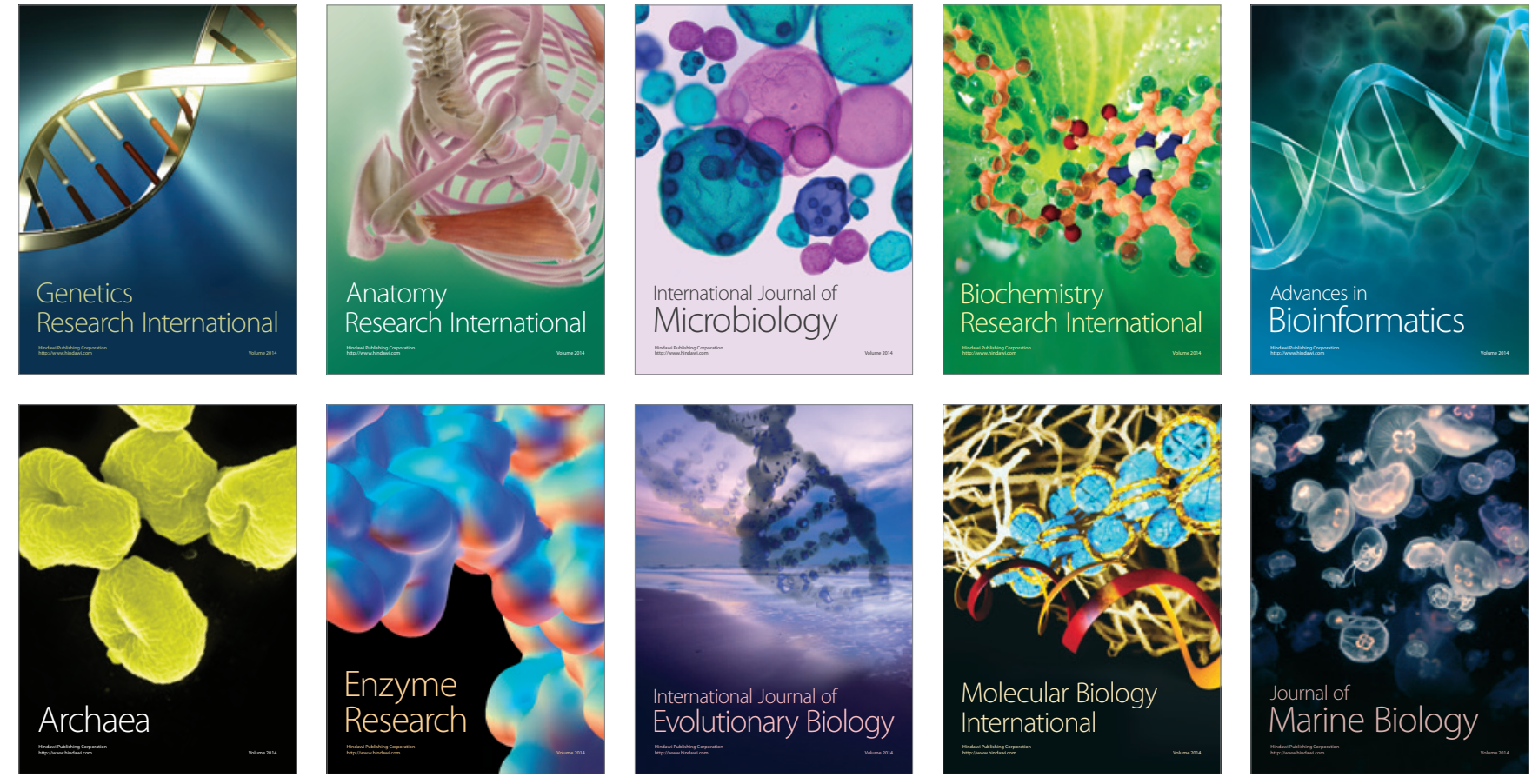